\title{
Characterization of banana starches obtained from cultivars grown in Brazil
}

\author{
Camila de Barros Mesquita ${ }^{a}$, Magali Leonel ${ }^{a, *}$, Célia Maria Landi Franco ${ }^{a, b}$, \\ Sarita Leonel ${ }^{a, c}$, Emerson Loli Garcia ${ }^{a}$, Thaís Paes Rodrigues dos Santos ${ }^{a}$ \\ a Center for Tropical Roots and Starches (CERAT), São Paulo State University (UNESP), Botucatu, São Paulo, Brazil \\ ${ }^{\mathrm{b}}$ Department of Food Engineering and Technology, Institute of Biosciences, Language, and Physical Sciences (IBILCE), UNESP, São José do Rio Preto, São \\ Paulo, Brazil \\ ${ }^{\mathrm{c}}$ Department of Horticulture, College of Agricultural Sciences (FCA), UNESP, Botucatu, São Paulo, Brazil
}

\section{A R T I C L E I N F O}

\section{Article history:}

Received 6 November 2015

Received in revised form 9 May 2016

Accepted 10 May 2016

Available online 11 May 2016

\section{Keywords:}

Musa spp.

Amylose

Viscosity

\begin{abstract}
A B S T R A C T
The starch market is constantly evolving and studies that provide information about the physical and rheological properties of native starches to meet the diverse demands of the sector are increasingly necessary. In this study starches obtained from five cultivars of banana were analyzed for size and shape of granules, crystallinity, chemical composition, resistant starch, swelling power, solubility, thermal and paste properties. The granules of starch were large (36.58-47.24 $\mu \mathrm{m})$, oval, showed crystallinity pattern type B and the index of crystallinity ranged from 31.94 to $34.06 \%$. The phosphorus content ranged from 0.003 to $0.011 \%$, the amylose ranged from 25.13 to $29.01 \%$ and the resistant starch ranged from 65.70 to 80.28\%. The starches showed high peak viscosity and breakdown, especially those obtained from 'Nanicão' and 'Grand Naine'. Peak temperature of gelatinization was around $71^{\circ} \mathrm{C}$, the enthalpy change $(\Delta \mathrm{H})$ ranged from 9.45 to $14.73 \mathrm{~J} \mathrm{~g}^{-1}$. The starch from 'Grand Naine' showed higher swelling power $\left(15.19 \mathrm{~g} \mathrm{~g}^{-1}\right) \mathrm{and} \mathrm{the}$ starch from 'Prata-Anã' higher solubility (11.61\%). The starches studied are highlighted by their physical and chemical characteristics and may be used in several applications.
\end{abstract}

(C) 2016 Published by Elsevier B.V.

\section{Introduction}

The banana (Musa spp.) is one of the fruits with the greatest production and consumption worldwide, being the base of the economy of some countries because of their dietary characteristics, which imply a high consumption in the various sections of society, representing the fourth food commodity in trading volume [1].

According to data from the Food and Agriculture Organization [2], in 2012 Brazil was the world's fifth largest banana producer, with 6.90 million tons, behind India (24.87 million), China (10.55 million), Philippines (9.23 million) and Ecuador (7.01 million). The national average productivity is still low, $14.56 \mathrm{t} \mathrm{ha}^{-1}$, below than performance of other countries leading the global market, such as Costa Rica, with production of 2.14 million tons and productivity of $54.1 \mathrm{tha}^{-1}$.

Banana is produced in all Brazilian states, being the largest producers in 2014: São Paulo, Bahia, Minas Gerais, Santa Catarina and

\footnotetext{
* Corresponding author.

E-mail addresses: mleonel@cerat.unesp.br, secretaria@cerat.unesp.br (M. Leonel)
}

Pará with production of respectively $1,133,819,1,088,647,711,397$, 701,501 and 588,655 tons and with a total production of 7.14 million tons [3]. However, the country, one of the major world producers, presents as one of the major problem in marketing high wastes in post-harvest [4].

The use of green bananas as a source of starch, since the pulp of the fruit in the ripening stage have $70-80 \%$ of starch in dry matter, decreases the wasted amount due to failures in the process of harvesting, storage and distribution.

Starch is a raw material abundant, renewable, biodegradable and non toxic which can be extracted with high purity by means of relatively simple industrial process and be easily converted into various products by chemical and biochemical processes. These factors, together, determine the agro-industrial potential immense of the starch.

About sixty million tones of starch are extracted annually worldwide from various cultures. About $60 \%$ of the produced starch is used in foods (bakery products, sauces, soups, candies, syrups, ice cream, chips, sausages, baby food, fat substitutes, specialty coffees, beers and other beverages) and $40 \%$ in pharmaceuticals and nonedible products purposes, such as fertilizers, seed coatings, paper, 
Table 1

Characteristics of banana cultivars.

\begin{tabular}{|c|c|c|c|c|c|}
\hline \multirow[t]{2}{*}{ Characters } & \multicolumn{5}{|l|}{ Cultivars } \\
\hline & Nanicão & Grand Naine & Prata Anã & Maçã & FHIA 18 \\
\hline Genomic group & AAA & AAA & $\mathrm{AAB}$ & $\mathrm{AAB}$ & AAAB \\
\hline Genomic subgroup & Cavendish & Cavendish & Prata & Prata & Prata \\
\hline Plant height & medium-low & medium-low & medium-low & medium-high & medium \\
\hline Tillering & medium & medium & good & optimum & good \\
\hline Growing season (days) & 290 & 290 & 280 & 300 & 327 \\
\hline Bunch weight $(\mathrm{kg})$ & 30 & 30 & 14 & 15 & 24.5 \\
\hline $\mathrm{N}^{\circ}$ fruits/bunch & 220 & 200 & 100 & 86 & 135 \\
\hline $\mathrm{N}^{\circ}$ hands/bunch & 11 & 10 & 7.6 & 6.5 & 9 \\
\hline Fruit length $(\mathrm{cm})$ & 23 & 20 & 13 & 13 & 20 \\
\hline Fruit weight (g) & 150 & 150 & 110 & 115 & 187 \\
\hline Yellow Sigatoka & $\mathrm{S}$ & $S$ & $S$ & MR & MR \\
\hline Black Sigatoka & $\mathrm{S}$ & $\mathrm{S}$ & $\mathrm{S}$ & $\mathrm{S}$ & $\mathrm{R}$ \\
\hline Fusarium wilt & $\mathrm{R}$ & $\mathrm{R}$ & MS & $S$ & $\mathrm{~S}$ \\
\hline
\end{tabular}

$\mathrm{S}=$ susceptible, $\mathrm{MS}=$ moderately susceptible, $\mathrm{R}=$ resistant, $\mathrm{MR}=$ moderately resistant.

cardboard, packaging materials, adhesives, textiles, diapers, bioplastics, building materials and oil drilling.

In view of the large application market of this polymer, investments in the areas of identifying new sources, cultural management, and also chemical, physical and biological modifications in order to obtain starches with a wide range of functional properties are needed to ensure compliance with such varied applicability purposes.

In a market in constant evolution and with an ever-stronger competition, the differentiating factor of an industry is the creation of new products and/or the production of products with improved characteristics. Thus, the search for native starches with properties that meet the different requirements of the consumer market has been one of the focuses of research in recent decades.

The banana is presented as a potential source of native starches with special properties. The starch of this fruit has shown interesting characteristics for industrial applicability as significant levels of amylose, high peak viscosity and final viscosity [5] and high levels of resistant starch [5-7].

Given the importance of new starchy raw materials, this study aimed to evaluate the physical, chemical, thermal and paste properties of starches extracted from five banana cultivars grown in Brazil.

\section{Materials and methods}

Five cultivars of banana were performed: 'Nanicão', 'Grand Naine', 'Maçã', 'Prata-Anã' and 'FHIA 18' (Table 1).

The cultivation of banana was conducted in São Manuel, São Paulo, Brazil $\left(22^{\circ} 46^{\prime} \mathrm{S}\right.$ latitude, $48^{\circ} 34^{\prime} \mathrm{W}$ longitude and altitude $740 \mathrm{~m}$ ) during the agricultural cycle $2014 / 2015$. The predominant climate type is temperate mesothermal, with rains in summer and dry in winter, with average temperature of the warmest month above $22^{\circ} \mathrm{C}$ and the average annual rainfall of $1377 \mathrm{~mm}$. The soil of the area is classified as Red-Yellow Dystrophic Latosol.

Soil analysis and the application of lime to raise the soil base saturation to $70 \%$ were conducted prior to orchard establishment. Seedling planting was held at $4 \mathrm{~m}$ spacing between rows and $2.5 \mathrm{~m}$ between plants in an area equivalent to $10 \mathrm{~m}^{2}$ by plant.

In the course of the experiment were performed: irrigation, weed control, thinning, removal of dried leaves, fertilization, pest control and disease, elimination of banana heart, removal of pistils and cutting pseudostem after harvesting.

Ten bunches from each cultivar were used to obtain the starches. The harvest of bunches occurred during the stage 1 of maturation of fruits, ie with fully green peel. The fruits were peeled, sliced and crumbled in an industrial blender in chilled water $\left(4^{\circ} \mathrm{C}\right)$ and ascor- bic acid (1\%) for the extraction of starches. Then, the material was centrifuged on a rotating sieve with a mesh of $0.25 \mathrm{~mm}$. The "starch milk" was purified in a centrifuge, and the pre-drying and drying steps performed in the vacuum filter and flash dryer.

\subsection{Morphology and size of granules}

The morphology of starches was observed by a scanning electron microscope (model Quanta 200, FEI Company). The samples were placed on stubs with double sided adhesive tape where the starches were fixed and covered with a gold layer of $20 \mathrm{~nm}$ sputter Balzers. The images were viewed, selected and saved by the software coupled to the equipment.

The granule size distribution was determined with laser diffraction using a Mastersizer 2000 (Malvern Instruments Ltd., Malvern, Worcestershire, UK), with the help of a Scirocco dry disperser unit used for dispersing the powders at a feed pressure of 2 bars and a feed rate of $40 \%$. The obscuration was in the interval of $0.5-5 \%$. The Fraunhofer approximation was used for calculation of the starch granules size distribution and the corresponding volume fractionlength mean diameter $\left(\mathrm{D}_{4,3}\right)[8]$.

\subsection{Crystallinity}

Samples of starch were kept in a desiccator containing saturated $\mathrm{BaCl}_{2}$ solution $\left(25^{\circ} \mathrm{C}\right.$, wa $\left.=0.9\right)$ for 10 days for moisture balance. Samples were packed in an aluminum holder and analyzed at room temperature by X-ray diffractometer (Rigaku Rotaflex, model RU 200 B, Tokyo, Japan) operating with monochromatic filter copper, $\mathrm{K} \alpha$ radiation, power of $0.8 \mathrm{~kW}$, current of $100 \mathrm{~mA}$, voltage of $50 \mathrm{kV}$ and rotating anode. The wavelength used was $1.542 \AA$ and a scan rate of $1 \mathrm{~min}^{-1}$. Analyses were performed between $3^{\circ}$ and $40^{\circ}$ in $2 \theta$. The peak intensity was expressed in counts per second (cps). Relative crystallinity was determined by the relationship between the peak area and the total area using software Origin version 7.5 (Microcal Inc., USA) [9].

\subsection{Physical and chemical composition of starches}

The starches were analyzed for moisture, ash, fiber, lipids, protein, starch, pH, titratable acidity [10], amylose apparent [11], resistant starch [12] and phosphorus [13].

\subsection{Pasting properties}

Pasting properties of banana starches were determined in a rapid visco analyzer (RVA 4, Newport Scientific, Australia) using $10 \%$ starch suspensions with a total mass of $27.5 \mathrm{~g}$. The program 
Table 2

Sizes of starches extracted from different cultivars of banana.

\begin{tabular}{ll}
\hline Varieties & Granules sizes $(\mu \mathrm{m})$ \\
\hline Nanicão & $47.24 \mathrm{a}$ \\
Grand Naine & $36.58 \mathrm{c}$ \\
Maçã & $41.88 \mathrm{~b}$ \\
Prata-Anã & $39.60 \mathrm{bc}$ \\
Fhia 18 & $41.31 \mathrm{~b}$ \\
CV $(\%)$ & 4.69 \\
LSD & 4.24
\end{tabular}

The same letter in the column do not differ statistically by Tukey test $(\mathrm{p}<0.05)$.

utilized was Starch $1\left(50^{\circ} \mathrm{C}\right.$ for $1 \mathrm{~min}$, heating from 50 to $95^{\circ} \mathrm{C}$ at a rate of $6^{\circ} \mathrm{C} \mathrm{min}^{-1}$, maintaining the paste at $95^{\circ} \mathrm{C}$ for $5 \mathrm{~min}$, cooling from 95 to $50^{\circ} \mathrm{C}$ at a rate of $\left.6{ }^{\circ} \mathrm{C} \mathrm{min}{ }^{-1}\right)$. The viscosity was expressed as RVU ( $1 \mathrm{RVU}=12 \mathrm{cp})$. From the graph obtained were evaluated: pasting temperature, maximum viscosity (peak), breakdown, final viscosity and setback. This analysis was carried out in triplicate.

\subsection{Thermal properties}

The thermal properties of potato starches were analyzed using a differential scanning calorimeter (DSC) Pyris 1 (Perkin Elmer, USA). Starch samples ( $2.0 \mathrm{mg}$, dry basis) were weighed into aluminum pans, mixed with deionized water $(6 \mu \mathrm{l})$ and sealed. The sealed pans were kept at room temperature for $2 \mathrm{~h}$ for balance and heated at a rate of $10^{\circ} \mathrm{C} \mathrm{min}^{-1}$ from $25^{\circ} \mathrm{C}$ to $100^{\circ} \mathrm{C}$. An empty aluminum pan was used as reference. After running the samples in DSC, they were refrigerated at $5{ }^{\circ} \mathrm{C}$ for 14 days and analyzed again under the same conditions to determine the thermal properties of retrograded starches. The gelatinization temperature (initial, peak and final) and the enthalpy change of native and retrograded starches were determined using the Pyris 1 software (Perkin Elmer, USA). This analysis was carried out in triplicate.

\subsection{Swelling powder (SP) and solubility index (S)}

Suspensions of $0.2 \mathrm{~g}$ of starches in $20 \mathrm{ml}$ of water were put in centrifugal tubes and heated in a water bath at temperatures of $95^{\circ} \mathrm{C}$ for $30 \mathrm{~min}$. In order to prevent water loss, all tubes were covered with plastic covers. After heating, samples were centrifuged (3000 rpm, $15 \mathrm{~min}$ ). Precipitated paste was separated from supernatant and had been weighed (Wp). Both phases were dried at $105^{\circ} \mathrm{C}$ for $24 \mathrm{~h}$ and the dry solids in precipitated paste (Wps) and supernatant (Ws) were calculated. SP is the ratio of the weight of swollen starch granules after centrifugation ( $g$ ) to their dry mass $(\mathrm{g})$. The $\mathrm{S}$ is the percentage of dry mass of solubles in supernatant to the dry mass of whole starch sample (Wo) [14].

\subsection{Statistical analysis}

Analysis of variance (ANOVA) and Tukey's test were used to conduct the statistical analysis of results. Significant differences were reported for $\mathrm{p}<0.05$. Pearson correlation coefficients were determined to evaluate relationship between variables.

\section{Results and discussion}

\subsection{Morphology and size of granules}

The morphology of starch granules depends on the biochemistry of amyloplast, as well as physiology of the plant. The results of the microscopic examination of banana starches showed that the starch granules of 'Nanicão' and 'Grand Naine' showed two major shapes: elongated and spherical. The starch of the cultivar 'Maçã' showed similar shapes, but the elongated are more narrow
Table 3

Crystalline area of starches.

\begin{tabular}{ll}
\hline Varieties & Crystallinity (\%) \\
\hline Nanicão & $33.43 \mathrm{a}$ \\
Grand Naine & $34.06 \mathrm{a}$ \\
Maçã & $32.15 \mathrm{a}$ \\
Prata-Anã & $31.94 \mathrm{a}$ \\
Fhia 18 & $33.41 \mathrm{a}$ \\
CV $(\%)$ & 5.24 \\
LSD & 3.78 \\
\hline
\end{tabular}

The same letter in the column do not differ statistically by Tukey test $(\mathrm{p}<0.05$ )

and long, similar to rods. The starches from 'Prata Anã' and 'FHIA 18 ' were elongated and oval. All the starch granules regardless of cultivar were flattened (Fig. 1).

Starches of five banana cultivars showed granules of various sizes with a smooth and dense surface, which can be related to resistance to enzymatic hydrolysis [15]. Studies have shown that the surface of the green bananas starch granules is smooth, while that of ripe bananas starches have parallel grooves [16].

The microscopic analyses of granules extracted from green bananas have shown a wide variety of shapes and sizes, being cited elongated and circular shapes, mainly $[17,18]$. The large granules are elongated and the small granules are rounded. Smaller granules are probably those in the training process, since the fruits are harvested at the green stage before the starch degradation, which occurs during fruit ripening. The size of the granules is very similar to granules of potatoes; however, in overall are larger [19].

The sizes of the starch granules were defined through the volume mean diameter (parameter D [4,3]). The 'Nanicão' showed higher value with $47.24 \mu \mathrm{m}$. The 'Grand Naine' cultivar, on the contrary, had the smallest diameter among the studied starches, $36.58 \mu \mathrm{m}$ (Table 2). The results obtained are within the size mentioned in the literature for banana starches, which vary from 20 to $60 \mu \mathrm{m}[18,20]$.

\subsection{Crystallinity}

Raw starch is a semi-crystalline material and the degree and type of crystallinity present is dependent mainly on the structural characteristics of amylopectin, though retrograded (re-associated) amylose also produces a unique type of crystalline structure [20].

The starches of the five cultivars of banana showed crystallinity range of $31.94-34.06 \%$, with no statistical differences between them (Table 3, Fig. 2). Starches obtained from banana cultivars showed B-type crystalline pattern, and its major peaks were at approximately $5^{\circ}, 15^{\circ}, 17^{\circ}, 22^{\circ}$ and $24^{\circ}$ in $2 \theta$. This crystalline pattern has been observed in banana starches [19,21]. However, some studies show that banana starches can have crystalline pattern of types A, B or C, depending on the variety of the banana, plant growth conditions, and other factors [19-23].

The structure of the crystalline pattern of type B has two D-glucose units in the unit cell, and shows a more open organization between the macromolecules with a water column present between the arrangements of double helices of amylopectin [24]. This fact contributes to penetration of water in the starch of type $B$. Furthermore, starches with crystalline pattern type A show higher water retention due to its compact structure. Starches with crystalline pattern type $B$ are more sensitive to hydrothermal treatment and there may be changes in the pattern of crystallinity of starch [25].

The starches types $\mathrm{B}$ and $\mathrm{C}$ tend to be more resistant to pancreatic amylases than type A [26]. This increased strength is due to branches and associations of amylopectin and amylose. In starches with pattern type A amylopectin has a high proportion of short chains. Already in the standards type $B$ and $C$ the amylopectin 

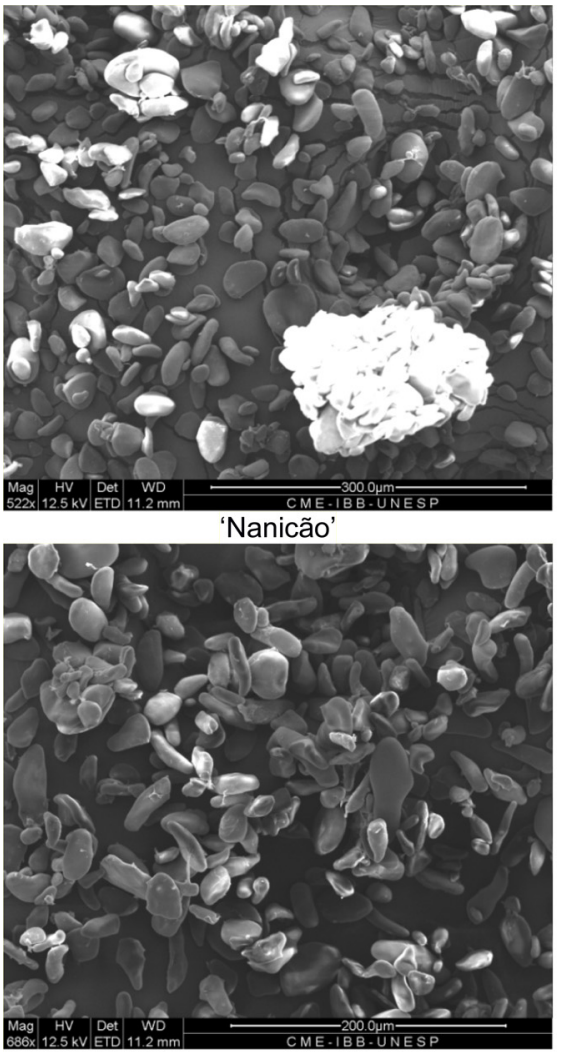

'Maçã'

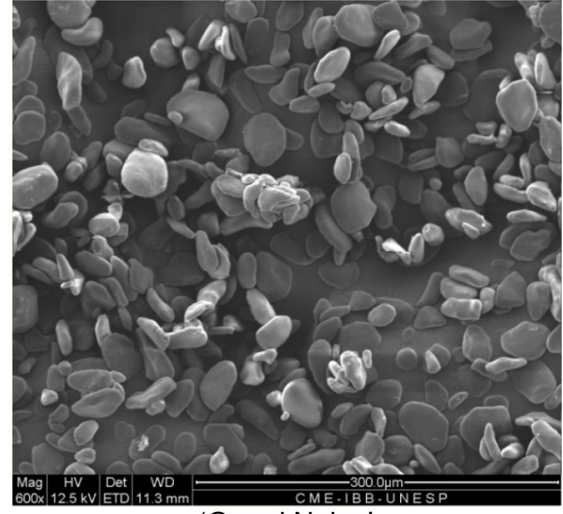

'Grand Naine'

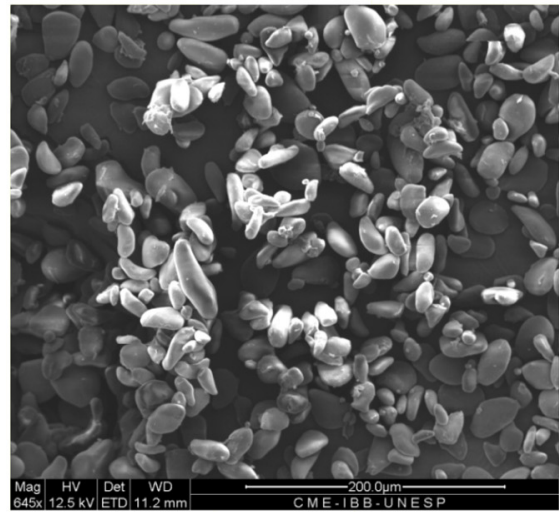

'Prata-Anã'

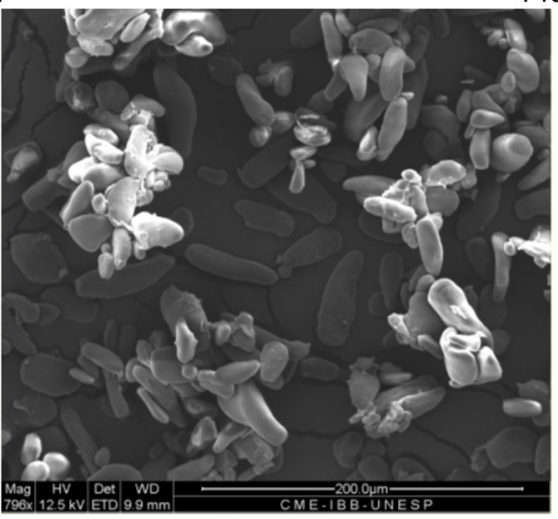

'FHIA 18'

Fig. 1. Shapes of granules of banana starches observed by scanning electron microscopy.

Table 4

Physical-chemical characteristics of banana starches (wet basis).

\begin{tabular}{|c|c|c|c|c|c|c|}
\hline Varieties & Nanicão & Grand Naine & Maçã & Prata-Anã & Fhia 18 & $\mathrm{CV}(\%)$ \\
\hline Moisture & $14.00 a$ & $10.82 b$ & $8.60 c$ & $9.90 \mathrm{bc}$ & $10.28 b c$ & 8.86 \\
\hline Ash & $0.13 c$ & $0.09 c$ & $0.26 b$ & $0.38 a$ & $0.34 \mathrm{ab}$ & 23.83 \\
\hline Protein & $0.61 b$ & $0.38 \mathrm{c}$ & $0.63 b$ & $0.99 a$ & $1.09 \mathrm{a}$ & 12.72 \\
\hline Fiber & $0.14 \mathrm{c}$ & $0.59 a$ & $0.47 \mathrm{ab}$ & $0.38 b$ & $0.18 c$ & 21.18 \\
\hline Lipids & $0.18 \mathrm{~d}$ & $0.26 c$ & $0.36 \mathrm{~b}$ & $0.46 a$ & $0.01 \mathrm{e}$ & 18.07 \\
\hline Starch & $84.94 d$ & $87.86 c$ & 89.67a & $87.88 \mathrm{c}$ & $88.08 b$ & 4.45 \\
\hline Titratable acidity & $0.71 \mathrm{~b}$ & $0.66 b$ & $0.85 a$ & $0.71 b$ & $0.91 \mathrm{a}$ & 9.44 \\
\hline $\mathrm{pH}$ & $6.56 a b$ & $6.76 a$ & $6.74 a$ & $6.02 c$ & $6.45 b$ & 2.29 \\
\hline
\end{tabular}

The same letter in the column do not differ statistically by Tukey test $(\mathrm{p}<0.05)$.

presents highly branched, forming long chains linked to amylose molecules [19].

The polymerization degree of the branched chains of amylopectin is related to the type of polymorphism and in B-type starches typically exhibit large portion of long-chain ( $D P \geq 37)$ [27].

\subsection{Physical and chemical composition}

The results obtained for the composition of the starches are shown in Table 4. The starch consists substantially of carbohydrates; however, substances such as lipids, proteins and ash are 
Table 5

Phosphorus, amylose and resistant starch contents of banana starches (wet basis).

\begin{tabular}{|c|c|c|c|}
\hline & Phosphorus (\%) & Amylose (\%) & Resistant starch (\%) \\
\hline Nanicão & $0.003 d$ & $25.31 d$ & $77.48 b$ \\
\hline Grand Naine & $0.003 d$ & $26.54 c$ & $82.67 a$ \\
\hline Maçã & $0.007 c$ & $29.01 a$ & $67.93 c$ \\
\hline Prata-Anã & $0.011 \mathrm{a}$ & $27.87 b$ & $81.65 a$ \\
\hline FHIA 18 & $0.010 \mathrm{~b}$ & $26.42 c$ & $65.91 c$ \\
\hline CV(\%) & 9.51 & 0.898 & 2.443 \\
\hline LSD & 0.0015 & 0.530 & 4.01 \\
\hline
\end{tabular}

The same letter in the column do not differ statistically by Tukey test $(\mathrm{p}<0.05)$.

Table 6

Pasting properties of starches obtained from different banana cultivars.

\begin{tabular}{|c|c|c|c|c|}
\hline \multirow[t]{2}{*}{ Varieties } & \multicolumn{4}{|l|}{ Viscosity } \\
\hline & Peak & Breakdown & Final & Setback \\
\hline Nanicão & $483.35 a$ & $246.96 a$ & $370.56 b$ & $134.17 \mathrm{bc}$ \\
\hline Grand Naine & $457.33 a$ & $204.31 a$ & $371.50 \mathrm{~b}$ & $118.48 \mathrm{bc}$ \\
\hline Maçã & $371.71 b$ & $103.44 b$ & $443.16 a$ & $177.39 a$ \\
\hline Prata-Anã & 369.02b & $147.69 b$ & $374.50 \mathrm{~b}$ & $153.17 \mathrm{ab}$ \\
\hline Fhia 18 & $386.79 b$ & $151.06 b$ & $350.17 b$ & $114.44 \mathrm{c}$ \\
\hline CV(\%) & 3.88 & 13.9 & 6.02 & 11.41 \\
\hline LSD & 35.04 & 51.83 & 50.22 & 34.80 \\
\hline
\end{tabular}

The same letter in the column do not differ statistically by Tukey test $(\mathrm{p}<0.05)$.

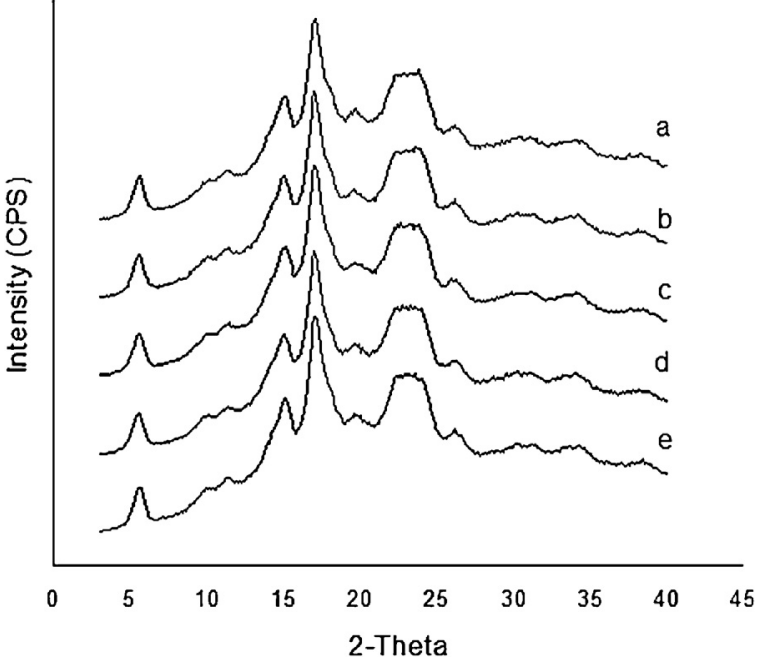

Fig. 2. X-ray diffraction patterns of starch granules of 'Nanicão' (a), 'Grand Naine' (b), 'Maçã' (c), 'Prata-Anã' (d) and 'FHIA 18' (e).

present in the composition. The amount of these constituents in the starch composition depends on the plant and the methods of extraction and purification [28]. Low contents of these substances indicate best commercial quality of starch.

In Brazil, the legislation that sets the standards to starches requires: $14 \%$ as the maximum moisture, $2 \%$ as maximum for titratable acidity, $80 \%$ as a minimum for the starch content, and the maximum values of $0.5 \%$ and $1.5 \%$ for ash and protein contents. Therefore, all banana starches can be classified as according to the rules established for marketing.

Since modifying the starch properties of banana by raising or lowering its phosphorus content suggests the possibility of its use in the making of value-added products, the measurement of the phosphorus content of banana starch is a promising means.

The phosphorus contents observed in banana starches ranged from 0.032 to $0.112 \%$ (Table 5). These values were higher than those cited by Zhu [29], who in their review about banana starch showed a range from 0.02 to $0.027 \%$. These variations may be related to the cultivar, soil type, physiological state of the plant, among others.
Phosphorus when covalently bound to the starch granule is able to assist the incorporation of water molecules, because of their ionic organization and thereby altering the functional properties of the starch such as gelatinization, retrogradation, viscosity and swelling power. Thus, high levels of phosphorus as those obtained for the starches from "Prata-Anã" 'and' 'FHIA18' are of great importance to the applicability of their starches.

Pearson correlation analysis showed positive correlation between phosphorus level and size of granule $(0.9616, \mathrm{p}=0.038)$ and viscosity peak $(0.9748, \mathrm{p}=0.025)$ for cultivar "Nanicão". In this same cultivar, phosphorus content was negatively correlated with range of temperature in gelatinization $(-0.9778, p=0.022)$. For the other cultivars, it was not observed significant correlation between phosphorus content and characteristics of starches.

The amylose content plays a central role affecting diverse physicochemical parameters of starches, since the amorphous fraction of starch granules is built up mainly of amylose, such as: functional properties of gelatinization and retrogradation of the starch and susceptibility to enzymatic hydrolysis [25,30]. The amylose content can vary within the same botanical variety because of differences in geographic origin and culture conditions. Amylose is anhydrous and can form excellent films, which are important characteristics for industrial applications.

The starch of the cultivar 'Maçã' had the highest amylose content (29.01\%), differing from the others (Table 5). The lowest amylose content was observed in starch extracted from 'Nanicão' (25.13\%). Amylose content greatly influences the physicochemical and functional properties of starch. Starch with high amylose content has a high resistance to digestion and provides many health benefits for humans.

The starches from bananas 'Kluai' showed amylose levels higher than those observed in studied cultivars, ranging from 38.6 to $43.8 \%$ [21]. Higher amylose values were observed for Valery cultivar (40.7\%). On the other hand, the amylose levels observed for 'PrataAnã' and 'Nanicão' were similar to those reported in the literature [7].

Pearson correlation analysis showed negative correlation between amylose and seatback in 'Maça' starch $(-0.9712$, $\mathrm{p}=0.029$ ). For other cultivars it was not observed significant correlation between amylose and other characteristics of starches. 
Table 7

Thermal properties of starches obtained from different banana cultivars.

\begin{tabular}{|c|c|c|c|c|c|}
\hline \multicolumn{6}{|l|}{ Gelatinization } \\
\hline & $\mathrm{T}_{0}\left({ }^{\circ} \mathrm{C}\right)$ & $\mathrm{T}_{\mathrm{p}}\left({ }^{\circ} \mathrm{C}\right)$ & $\mathrm{T}_{\mathrm{f}}\left({ }^{\circ} \mathrm{C}\right)$ & $\Delta \mathrm{T}\left({ }^{\circ} \mathrm{C}\right)$ & $\Delta \mathrm{H}\left(\mathrm{Jg}^{-1}\right)$ \\
\hline Nanicão & $68.07 a$ & $70.58 a$ & 73.73a & $5.65 b$ & $14.73 a$ \\
\hline Grand Naine & $68.65 a$ & 71.11a & $74.21 \mathrm{a}$ & $5.56 \mathrm{~b}$ & $13.22 \mathrm{ab}$ \\
\hline Maçã & $69.23 a$ & $72.17 \mathrm{a}$ & $75.36 a$ & $6.13 b$ & $10.61 \mathrm{bc}$ \\
\hline Prata-Anã & 67.79a & 71.02a & $74.64 a$ & $6.85 a$ & $12.94 \mathrm{ab}$ \\
\hline FHIA 18 & $68.5 a$ & 71.69a & $74.67 a$ & $6.13 b$ & $9.45 c$ \\
\hline CV (\%) & 1.60 & 1.59 & 1.44 & 4.59 & 10.36 \\
\hline LSD & 2.39 & 2.47 & 2.34 & 0.61 & 2.76 \\
\hline \multicolumn{6}{|c|}{ Retrogradation } \\
\hline & $\mathrm{T}_{\mathrm{o}}\left({ }^{\circ} \mathrm{C}\right)$ & $\mathrm{T}_{\mathrm{p}}\left({ }^{\circ} \mathrm{C}\right)$ & $\mathrm{T}_{\mathrm{f}}\left({ }^{\circ} \mathrm{C}\right)$ & $\Delta \mathrm{T}\left({ }^{\circ} \mathrm{C}\right)$ & $\Delta \mathrm{H}\left(\mathrm{Jg}^{-1}\right)$ \\
\hline Nanicão & 44.40ab & $53.05 a$ & $59.31 b$ & $14.91 b$ & $6.51 \mathrm{ab}$ \\
\hline Grand Naine & 43.45ab & $52.88 \mathrm{a}$ & 61.24ab & 17.79ab & $6.25 b$ \\
\hline Maçã & $45.56 a$ & $53.43 a$ & 61.93ab & $16.37 b$ & $4.16 c$ \\
\hline Prata-Anã & $41.66 b$ & $51.80 \mathrm{a}$ & $63.06 a$ & $21.39 \mathrm{a}$ & $6.94 a$ \\
\hline FHIA 18 & 45.01ab & 53.07a & $61.02 \mathrm{ab}$ & $16 b$ & $6.25 b$ \\
\hline CV (\%) & 3.81 & 1.80 & 2.03 & 11.31 & 3.72 \\
\hline LSD & 3.66 & 2.07 & 2.72 & 4.28 & 0.49 \\
\hline
\end{tabular}

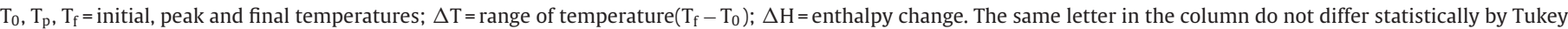
test $(\mathrm{p}<0.05)$.

Resistant starch (RS) is defined as the sum of starch and products of starch degradation not absorbed in the small intestine of a healthy individual. There are four types of resistant starch: type I, which represents physically inaccessible starch that is locked in the plant cell walls of some food stuffs such as partially milled grains, seeds and legumes; type II, which is characterized by native granular starch found in bananas, raw potatoes and beans; type III, which comprises retrograded starch and type IV, which includes chemically modified starches that are used by food manufacturers to improve the functional characteristics of the starch [21].

It has been shown that banana starch appears to be resistant to enzyme-catalyzed hydrolysis. Banana starches extracted from different cultivars had a variation between 65.91 and $82.67 \%$ of the total resistant starch (Table 5). The study of Vatanasuchart et al. [21] on eleven banana cultivars grown in Thailand shows that the RS content observed in the common cultivars ranged from 52.2 to $61.4 \%$ and values for indigenous cultivars were between 50.7 and $68.1 \%$. Contents ranging from 27.4 to $91.9 \%$ also have been shown for banana starches $[8,25]$.

It has been reported relationship between the crystalline pattern of starches and their resistance to hydrolysis. Starches with crystalline pattern of type A, B and C show different susceptibilities to amylase hydrolysis. Generally, the starch of type B or C shows more resistance to enzyme hydrolysis than the starch with crystalline pattern type A [15].

\subsection{Paste properties}

Starch, when heated in the presence of excess water, undergoes the order to disorder phase transition known as gelatinization over a typical temperature range of the starch source. Starch paste properties are affected by the amylose, lipids, and phosphorus contents and by the distribution of lengths of branched chains of amylopectin [31].

The pasting characteristics play an important role in the selection of a variety for use in the industry as a thickener and binder [32]. The results obtained for the paste properties of banana starches are shown in Table 6 and Fig. 3. Results showed significant differences among cultivars for the measured properties. The starches from the cultivars 'Nanicão' and 'Grand Naine', same genomic group, showed similar behavior: smallest paste temperatures, as well as, highest peak viscosity, breakdown and final

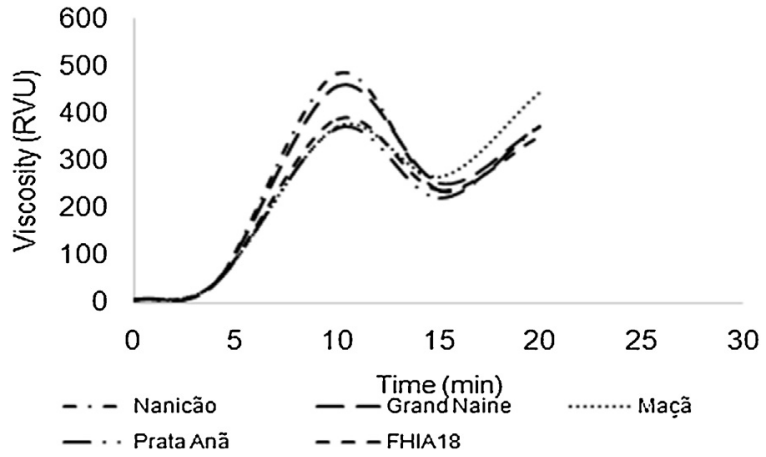

Fig. 3. Viscosity curves of banana starches measured with a Rapid Visco Analyser (RVA).

viscosity. They also contain low levels of lipids, phosphorus and amylose, assisting the pasting process.

In general, the analyzed banana starches showed paste temperatures ranging from 74.41 to $79.85^{\circ} \mathrm{C}$, low peak viscosity (371.71-483.35 RVU), considerable resistance to mechanical agitation, with breakdown ranging from 106.77 to 269.75 RVU, low final viscosity and seatback, which highlights different applicability for this starch.

\subsection{Thermal properties of banana starches}

Thermal properties of the banana starches, measured by DSC, differed significantly. Endothermic peaks in gelatinization for starches from different banana cultivars appeared between 67.79 and $75.36^{\circ} \mathrm{C}$. In retrogradation, endothermic peaks ranged from 41.66 to $63.06{ }^{\circ} \mathrm{C}$. The transition temperatures $\left(\mathrm{T}_{0}, \mathrm{~T}_{\mathrm{p}}\right.$ and $\left.\mathrm{T}_{\mathrm{f}}\right), \Delta \mathrm{T}$ and $\Delta \mathrm{H}$ of banana starches in gelatinization and retrogradation are summarized in Table 7.

The starch crystallinity can be estimated by the enthalpy change $(\Delta \mathrm{H})$ required to fuse the segments double helices. The gelatinization temperature (initial and peak) can be used as a measure of stability or completeness of the crystalline regions, and the width of the endothermic peak to estimate the heterogeneous crystalline structure.

The $\Delta \mathrm{T}$ indicates the degree of heterogeneity of the crystals within the granules, while the $\Delta \mathrm{H}$ reflects the amount of double 
Table 8

Swelling power and solubility of banana starches.

\begin{tabular}{lll}
\hline & $\mathrm{SP}\left(\mathrm{g} \mathrm{g}^{-1}\right)$ & $\mathrm{S}(\%)$ \\
\hline Nanicão & $13.20 \mathrm{~b} \pm 0.10$ & $5.44 \mathrm{~b} \pm 0.92$ \\
Grand Naine & $15.19 \mathrm{a} \pm 0.26$ & $6.85 \mathrm{~b} \pm 1.23$ \\
Maçã & $14.42 \mathrm{a} \pm 1.40$ & $9.88 \mathrm{a} \pm 2.42$ \\
Prata-Anã & $14.66 \mathrm{a} \pm 0.43$ & $11.61 \mathrm{a} \pm 1.64$ \\
Fhia 18 & $14.88 \mathrm{a} \pm 0.21$ & $6.67 \mathrm{~b} \pm 1.31$ \\
\hline
\end{tabular}

The same letter in the column do not differ statistically by Tukey test $(\mathrm{p}<0.05)$.

helices that are broken during gelatinization [33]. Thus, the starch of the 'Prata-Anã' showed a lower homogeneity of its crystalline area compared to other cultivars.

Starches obtained from 'Nanicão' and 'FHIA 18' showed the extreme values of enthalpy change $(\Delta \mathrm{H}), 14.73$ and $9.45 \mathrm{Jg}^{-1}$, respectively.

The starches of 'Nanicão' and 'Grand Naine' contains low amylose content, therefore, have more amylopectin chains in their structure compared to the starches of other cultivars. This implies greater energy to break double helices, which explains the change in enthalpy. Enthalpy change of gelatinization primarily reflects the loss of double helical order and decreases with amylose content increase.

The thermal properties observed for banana starches were similar to those reported in other studies with starch obtained from different banana cultivars $[19,34,35]$.

The behavior of gelatinized starches on cooling and storage is of great interest to food scientists and technologists since it profoundly affects quality, acceptability and shelf-life of starchcontaining foods [36].

The molecular interactions (hydrogen bonding between starch chains) after cooling of the gelatinized starch paste have been called retrogradation. During retrogradation, amylose forms doublehelical associations of 40-70 glucose units whereas amylopectin crystallization occurs by association of the outermost short branches.

The initial gelatinization temperature of the starch in retrogradation ranging from 41.66 to $45.56^{\circ} \mathrm{C}$, with the lowest temperature observed for the starch of the cultivar 'Prata-Anã'. Peak temperatures did not differ between the cultivars, ranging from 51.80 to $53.43^{\circ} \mathrm{C}$. The final temperature variation ranged from 59.31 to $63.06{ }^{\circ} \mathrm{C}$ with the lowest temperature observed in the starch of the 'Nanicão' (Table 7).

The $\Delta \mathrm{H}$ after retrogradation demonstrates the capacity of association between amylose and amylopectin. The presence of a minor change of enthalpy reveals that there was fusion between starch fractions.

Retrograded starches show lower gelatinization and enthalpy change than native starches because they have weaker starch crystallinity.

The variation in thermal properties of starches after gelatinization and during refrigerated storage may be attributed to the variation in amylose to amylopectin ratio, size and shape of the granules and presence/absence of lipids.

\subsection{Swelling capacity and solubility}

One of the most important structural characteristics of starch is that it passes through several different stages from water absorption to granule disintegration. Water absorption and consequent swelling of the starch granule contribute to amylopectin-amylose phase separation and crystallinity loss, which in turn promotes the leaching of amylose to the intergranular space [37].

The swelling capacity indicates the strength of penetration of water into starch granules. The crystalline areas maintain the integrity of the granules, allowing the swelling but not complete dispersal of the macromolecules. During the heating an aqueous starch suspension, the amorphous areas quickly absorb water and swell, remain together by the crystalline regions. The temperature increase weakens the molecular bonds between the starch granule structures, facilitating the action of water and its retention within the granule [38-40].

Swelling capacity is an indication of the strength of water binding forces in starch granules. In fact, the mobility of starch molecules is increased with temperature, thereby weakening binding forces. Hence, the leaching of soluble components is augmented, yielding improved starch solubility and increased granule porosity. An effect of this process is the increase of the effective diffusivity of water into the granule structure and, together with the flexibility of high molecular number of starch molecules, improves water retention [25].

The results obtained for the swelling power and solubility of starches extracted from different banana cultivars are presented in Table 8.

The swelling capacity of the banana starch ranges from 13.20 to $15.19 \mathrm{~g} \mathrm{~g}^{-1}$, with the lowest value observed for the starch from 'Nanicão', which may be related to low phosphorus and amylose contents. The swelling capacity of starch is directly associated with the amylopectin content because the amylose acts as a diluent and inhibitor of swelling.

When starch molecules are heated in excess water, the crystalline structure is disrupted and water molecules become linked by hydrogen bonding to the exposed hydroxyl groups of amylose and amylopectin. The lower swelling power and solubility of 'Nanicão' starch can be probably due to a lower content of phosphate groups on amylopectin. The repulsion between phosphate groups on adjacent chains increase hydration by weakening the extent of bonding within the crystalline domain.

Higher amylose content in starch granule increases solubilization capacity in aqueous solution because of the leaching process of amylose at high temperatures.

Significant differences among cultivars were observed in the analysis of solubility of the starches. Starches obtained from the cultivars 'Maçã' and 'Prata Anã' showed higher solubility.

\section{Conclusions}

Starches extracted from banana cultivars differ in their characteristics; however, we observed that they show large and oval granules with high resistance to enzymatic action. These starches show crystallinity pattern type $\mathrm{B}$, a considerable percentage of amylose, low phosphorus content, high peak viscosity and low resistance to heat and agitation, with gelatinization temperature around $71^{\circ} \mathrm{C}$.

Due to their characteristics the starches obtained from green bananas show relevance and use potential in replacement of starches commonly used in industry. The production of banana starch would increase the starch market in Brazil as well as the wastage of fruit in the banana trade.

\section{References}

[1] AACC. American Association of Cereal Chemists, Approved Methods of the AACC, 1st ed., AACC, St. Paul, 1983.

[2] FAO Food and Agriculture Organization, ProductionCrop Data, 2015, Available from: http://faostat.fao.org/site/\%20339/default.aspx.

[3] IBGE Instituto Brasileiro de Geografia e Estatística, Levantamento Sistemático da Produção Agrícola, LSPA, Rio de Janeiro, 2015, pp. 1-83.

[4] A.M. Borges, J. Pereira, E.M.P. Lucena, Green banana flour characterization, Food Sci. Technol. 29 (2009) 333-339.

[5] M. Leonel, E.L. Carmo, S. Leonel, C.M.L. Franco, R.B. Campanha, Starch extraction and characterization of different cultivars of banana, Rev. Bras. Frutic. 33 (2011) 599-605. 
[6] E. Agama-Acevedo, M.C. Nuñez-Santiago, J. Alvarez-Ramirez, L.A. Bello-Perez Physicochemical, digestibility and structural characteristics of starches isolated from banana cultivars, Carbohydr. Polym. 124 (2015) 17-24.

[7] S.M. Londono-Restrepo, N. Rincón-Londonõ, M. Contreras-Padilla, A.A. Acosta-Osorio, L.A. Bello-Pérez, L.C. Lucas-Aguirre, V.D. Quintero, P. Pineda-Gómez, A. del Real-López, M.E. Rodríguez-García, Physicochemical, morphological, andrheological characterization of Xanthosoma robustum Lego-likestarch, Int. J. Biol. Macromol. 65 (2014) 222-228.

[8] Z. Fu, L. Wangb, D. Li, B. Adhikari, Effects of partial gelatinization on structure and thermal properties of corn starch after spray drying, Carbohydr. Polym. 88 (2012) 1319-1325.

[9] S. Nara, T. Komiya, Studies on the relationship between water-saturated state and crystallinity by the diffraction method for moistened potato starch, Starch/Starke 35 (1983) 407-410.

[10] AOAC, Official Methods of Analysis, 18th ed., Association of Official Analytical Chemists, Gaithersburg, Current Through Revision 2, 2007.

[11] ISO, International Standardization Organization. Rice; Determination of amylose content. ISO 6647, 1987. 5p.

[12] I. Goñi, E.M. Garcia-Diz, F. Saura-Calixto, Analysis of resistant starch: a method for foods and food products, Food Chem. 56 (1996) 445-449.

[13] E. Malavolta, G.C. Vitti, S.A. de Oliveira, Avaliação do estado nutricional das plantas: princípios e aplicações, 2nd ed., Associação Brasileira para Pesquisa da Potassa e do Fosfato, Piracicaba, 1997, p. 308.

[14] J.T. Schoch, Swelling power and solubility of granular starches, in: L.R. Whistler, J.R. Smith, N.J. BeMiller (Eds.), Methods in Carbohydrate Chemistry, Academic Press, London, 1964, pp. 106-113.

[15] R.F. Tester, J. Karkalas, X. Qi, Starch composition, fine structure and architecture, J. Cereal Sci. 39 (2004) 151-165.

[16] K. Kayisu, L.F. Hood, Molecular structure of banana starch, J. Food Sci. 46 (1981) 1894-1897.

[17] B.R. Cordenunsi, F.M. Lajolo, E.W. Menezes, Utilização de novas técnicas de microscopia na caracterização do amido, Carboidratos em Alimentos RegionaisIbero-americanos, USP, São Paulo, 2006, p. 646.

[18] R.G. Utrilla-Coello, M.E. Rodríguez-Huezo, H. Carrillo-Navas, C. Hernández-Jaimes, E.J. Vernon-Carter, J. Alvarez-Ramirez, In vitro digestibility, physicochemical, thermalandrheologicalpropertiesof bananas starches, Carbohydr. Polym. 101 (2014) 154-162.

[19] D.R. Izidoro, M.R. Sierakowski, C.W.I. Haminiuk, C.F. de Souza, A.P. Scheer, Physical and chemical properties of ultrasonically, spray-dried green banana (Musa cavendish) starch, J. Food Eng. 104 (2011) 639-648.

[20] P. Zhang, R.L. Whistler, J.N. Bemiller, B.R. Hamaker, Banana starch: production, physicochemical and disgestibility-a review, Carbohydr. Polym. 59 (2005) 443-458.

[21] N. Vatanasuchart, B. Niyomwit, K. Wongkrajang, Resistant starch content, in vitro starch digestibility and physico-chemical properties of flour and starch from Thai bananas, MaejoInt. J. Sci. Technol. 6 (2012) 259-271.

[22] N. Faisant, A. Buléon, P. Colonna, C. Molis, S. Lartigue, J.P. Galmiche, M. Champ, Digestion of raw banana starch in the small intestine of healthy humans: structural features of resistant starch, Br. J. Nutr. 73 (1995) 11-123.

[23] T. Tongdang, T. Saasagul, Some properties of banana starches extracted from two varieties, Conference on Starch Technology, Bangkok/Thailand, Proceedings of Starch Update (2005) 199-200.
[24] O.J. Gallant, P. Bouchet, P.M. Baldwin, Microscopy of starch: evidence of a new level of granule organization, Carbohydr. Polym. 32 (1997) 177-191.

[25] A.N. Jyothi, M.S. Sajeev, J.N. Sreekumar, Hydrothermal modifications of tropical tuber starches. Effect of heat-moisture treatment on the physicochemical, rheological and gelatinization characteristics, Starch/Starke 62 (2010) 28-40

[26] M.C.J. Freitas, D. de, Q. Tavares, Caracterização do grânulo de amido de bananas (Musa AAA-NANICÃO e Musa AAB-TERRA), Ciênc. Tecnol. Aliment. 25 (2005) 217-222.

[27] S. Hizukuri, T. Kaneko, Y. Takeda, Measurement of the chain length of amylopectin and its relevance to the origin of crystalline polymorphism of starch granules, Biochim. Biophys. Acta 760 (1983) 188-191.

[28] F.H.G. Peroni, T.S. Rocha, C.M.L. Franco, Some structural and physicochemical characteristics of tuber and root starches, Food Sci. Technol. Int. 12 (2006) 505-513.

[29] F. Zhu, Composition, structure, physicochemical properties and modifications of cassava starch, Carbohydr. Polym. 122 (2015) 456-480.

[30] C. Gérard, C.P. Barron, V. Planchot, Amylose determinations in genetically modified starches, Carbohydr. Polym. 44 (2001) 19-27.

[31] R.F. Tester, W.R. Morrison, Swelling and gelatinization of cereal starches. Effects of amylopectin, amylose, and lipids, Cereal Chem. 67 (1990) 551-557.

[32] T.P.R. Santos, M. Leonel, E.L. Garcia, E.L.do Carmo, C.M.L. Franco, Crystallinity, thermal and pasting properties of starches fromdifferent potato cultivars grown in Brazil, Int. J. Biol. Macromol. 82 (2016) 144-149.

[33] D. Cooke, M.J. Gidley, Loss of crystallinity and molecular order during starch gelatinization: origin of the enthalpic transition, Carbohydr. Res. 227 (1992) $103-112$.

[34] L.A. Bello-Pérez, E. Agama-Acevedo, S.G. Sayago-Ayerdi, E. Moreno-Damian, J.D.C. Figueroa, Some structural, physicochemical and functional studies of banana starches isolated from two varieties growing in Guerrero, Mexico, Starch/Stärke 52 (2000) 68-73.

[35] M.C. Núñez-Santiago, L.A. Bello-Pérez, A. Tecante, Swelling-solubility characteristics, granule size, distribution and rheological behavior of banana (Musa paradisiacal) starch, Carbohydr. Polym. 56 (2004) 65-75.

[36] A. Karim, M.H. Norziah, C.C. Seow, Methods for the study of starch retrogradation, Food Chem. 71 (2000) 9-36.

[37] S.C. Alcázar-Alay, M.A.A. Meireles, Physicochemical properties, modifications and applications of starches from different botanical sources, Food Sci. Technol. 35 (2015) 215-236.

[38] H.W. Leach, L.D. McCowen, T.J. Schoch, Structure of the starch granule. Swelling and solubility patterns of various starches, Cereal Chem. 36 (1959) 534-544.

[39] S. Nara, T. Komiya, Studies on the relationship between water-satured state and crystallinity by the diffraction method for moistened potato starch, Starch/Stärke 35 (1983) 407-410.

[40] O.S. Lawal, R. Lapasin, B. Bellich, T.O. Olaywola, A. Cesàro, M. Yoshimura, Rheology and functional properties of starches isolated from five improved rice varieties from West Africa, Food Hydrocolloids 25 (2011) 1785-1792. 